\title{
Analysis on Effective Methods and Means for Modern Education to Cultivate Innovation Consciousness and Practical Ability of Students
}

\author{
Qingzhu Dong \\ Huanghe Science and Technology College \\ Zhengzhou, China 450005
}

\begin{abstract}
Improving innovation consciousness and practical ability of students is the objective requirement of social development; practical needs of quality-oriented education; requirements to carry forward nature of innovation. The cultivation of innovation consciousness and practical ability is a systematic project. It runs through the whole process of talent cultivation and penetrates in all aspects of teaching process. This article mainly analyzes from improving innovation consciousness of students and practical significance of practical ability, then puts forward effective methods and means for modern education to cultivate innovation consciousness and practical ability, in order to provide reference for modern educators.
\end{abstract}

Keywords—innovation consciousness; practical ability; methods; means

\section{PRACTICAL SIGNIFICANCE TO IMPROVE INNOVATION} CONSCIOUSNESS AND PRACTICAL ABILITY OF STUDENTS

Improving innovation consciousness and practical ability of students is the objective requirement of social development; practical need of quality-oriented education; requirement to carry forward nature of innovation.

A. Improving Innovation Consciousness and Practical Ability of Students Is the Objective Requirement of Social

\section{Development}

Under the situation of modern society that economic development accelerates increasingly, knowledge increases sharply and technology updates continuously, it expresses newer and higher requirements for talents. Contemporary talents must have survival ability to learn, adapt, innovate and compete. Therefore, in this era of competition and development, the effect of innovation in social development is increasingly obvious and big. It has become basic requirement and prerequisite for survival and development of human beings and the great event related to rise and fall of a country and nation. So innovation is the permanent theme of social development and progress of human beings. Cultivating innovation consciousness and practical ability is the objective requirement of modern society for quality-oriented education and basic requirement to meet the challenge of new era.

\section{B. It Is the Realistic Requirement of Quality-oriented Education to Improve Innovation Consciousness and Practical Ability of Students in Contemporary Era}

At present, cultivating students' innovation consciousness and practical ability is the key point of quality-oriented education, the core of quality-oriented education, the priority among priorities of basic education reform, as well as one of the basic tasks in the cross-century education reform. As early as 1999 , our country puts forward "the education that uses new educational thought and educational concept as the guidance, adopts modern educational technology and means of information, with the purpose to train students to learn and create and make them have spirit of innovation, consciousness of innovation, innovation ability and innovative personality." Therefore, it can be seen that in the process of contemporary education and teaching, it is the goal and requirement of educational reform of our country as well as objective require ment of quality-oriented education to cultivate students' innovation ability and practical ability. From the pers pective of social pedagogy, the process of education is the process to make people transfer from biological entity to social entity, that is to say, the process to make people realize socialization gradually. Therefore, only through innovation education can make people change from social entity of certain level to social entity of higher level and make people move towards selfimprovement. To sum up, innovation consciousness and practical ability are important embodiments of quality-oriented education. Only through paying attention to students' innovation conscious ness and practical ability in contemporary education and teaching can help students' growth and development and lay solid foundation for them to grow into highly-competent people. Only through innovation education can cultivate talents with innovation consciousness and practical quality in contemporary era.

\section{It Is the Requirement of Carrying Forward the Nature of Innovation to Improve Innovation Consciousness and Practical Ability of Students}

Innovation is the permanent theme for development and progress of human society. Innovation is the highest nature of human. Aristotle says, "Seeking knowledge is the nature of human". Landman, the German anthropologist, says, "If human have something that cannot change, it is the innovation 
nature of human". This shows that people have great plasticity. They are good at gaining experience and knowledge through production, activity and practice, then develop themselves, change the world and innovate continuously. People always seek new survival and development through their own practice. Nowadays, in contemporary era, the competition between countries is the competition of talents, which is the competition of creativity in nature. Therefore, it becomes basic requirement of the era for human to improve subjective initiative of people and cultivate innovation consciousness and practical ability of people. Innovation consciousness and practical ability have become important embodiment of personal value.

\section{EFFECTIVE METHODS AND MEANSTO CULTIVATE INNOVATION CONSCIOUSNESS AND PRACTICAL ABILITY}

\section{A. It Is Necessary to Establish New Educational Concept and Make Efforts to Cultivate the Consciousness of Modern Talents Corresponding to Consciousness of Innovation}

- In modern education, exploring new education concept is an important value embodiment to cultivate students' innovative practical ability. As early as 1943, Mr. Tao Xingzhi, a famous educator of our country, put forward the creative educational view, "The place of creation is in everywhere, people can create everyday, everyone can create". Therefore, we shall make good use of the "favorable climatic, geographical and human conditions" full of the power of creativity in everywhere, consciously guide students to experience, stimulate students' desire for independent and creative learning, let students seek innovation and gain practice in independence to realize their own value. From the perspective of society, the values education of innovation and practice are the core embodiment of quality-oriented education, as well as the embodiment to go beyond oneself, break through oneself and realize innovative development. Innovation consciousness and practical ability are not only intellectual characteristics of a people, but also concrete embodiment of personality characteristics, mental state and comprehensive quality. From the perspective of educator, exploring new educational concept and making efforts to cultivating students' comprehensive innovation quality is sacred duty of educators and important value embodiment to cultivate the development of students' innovative practical ability. Teachers can cultivate more talents with innovation ability and adapt to requirements of development of the present era through combining concrete teaching practice, making efforts to seek ways to cultivate students' innovative learning from different aspects, exploring effective training methods and taking the development of students' innovation potential as basic tasks.

- Establishing innovative education view is important embodiment of functional concept of education. To some extent, contemporary education needs to surpas $\mathrm{s}$ the functions of traditional education to pass on knowledge, impart professional knowledge and solve problems. The fundamental mission and fundamental task of teachers are to cultivate innovation consciousness and practical ability of students. They can cultivate spirit of innovation of students through teaching practice, innovative education model and method. Therefore, in modern education, it is necessary to further free our mind, change traditional educational concept, and take the establishment of innovative educational idea as the guidance, change untimely traditional educational concept, change the educational concept in traditional teaching that turns from teachercentered model to student-oriented model dominated by teachers, highlight people oriented thought, change educational concept of traditional teaching that tums from imparting knowledge for students to paying equal attention to imparting knowledge and cultivating quality and ability of students, make the main thought prominent about cultivating creative spirit and practical ability of students. Thus it can further stimulate independent thinking and innovation consciousness of students, feel and understand the processes of generation and development of knowledge, effectively build the education system to cultivate scientific spirit and ability of creative thinking of students. Innovation education is an effective way to cultivate innovation spirit and practical ability of students. It is the main characteristic of educational development at present.

- Establishing innovation consciousness and practical ability is an important standard of new outlook on talents. Under talent standard at new period, it is an important standard of new outlook on talents to have innovation consciousness and practical ability. The cognition and opinion on evaluation of people on students, teachers and school also realize new transcendence. Especially on innovative education model, pay attention to protecting and supporting students who "like to take unnecessary pains to study an insignificant problem" and "like to play petty tricks" on learning, encourage them to try, do something unconventional and unorthodox, do not fear failure, make endeavor to cultivate their learning quality of exploration and innovation and creatively finish learning tasks. If we want to develop the economy, the education shall go ahead of the rest. If we want to develop education, teachers shall go ahead of the rest. Objectively, it requires teachers to create something new and original, adopt forms such as target teaching, democratic discussion and lectures about problems, practice and innovate with students to realize teaching benefits teachers as well as students. Schools shall seek development in constant innovation and innovate in teaching, teaching management and decision-making and form scientific, democratic and efficient management decision mechanism. 


\section{B. Make Efforts to Realize the Change to Innovate in} Classroom Teaching Idea

- Innovate in classroom teaching model and create situation of consciousness of problems. Strengthening students' consciousness of problems is the starting point to cultivate students' innovation consciousness. Because of being influenced by traditional education, most students have relatively weak consciousness of problems, which is embodied in the following two kinds: The first is that students are afraid of or unwilling to raise questions. The second is that students are unable or not good at raising questions. Although the former has certain consciousness of problems, it does not show but remain the underlying state. The latter is that because of various factors such as teaching and learning, students are not good at thinking and have laziness in thinking. They are unable to or not good at raising questions, with little or no consciousness of problems. Thus, cultivating students' consciousness of problems is also one of the important tasks of innovative teaching idea at present. In reality, classroom teaching is the teaching of human. It is also one of the important tasks for contemporary educators to deeply research and realize the change to innovate in classroom teaching idea about how to innovate in classroom teaching model, improve the cultivation of students' innovative consciousness and practical ability as well as vividly and effectively achieve the teaching goal.

- Change teaching methods and master methods and art of innovative and practical ability. Teachers are instructors for development of students' innovative consciousness and practical ability and play an important role in form and improvement of students' knowledge, ability and quality, especially play a decisive influence on cultivating creative spirit and practical ability of students. Therefore, teachers' innovation consciousness and practical ability will directly influence students' quality. It requires teachers to have certain methods and art to cultivate innovation consciousness and practical ability, design teaching process and change teaching methods according to teaching contents, quality of students and differences between students, and pay attention to inspiring students' innovative thinking and cultivation of operational capacity to solve practical problems according to specific circu mstance in teaching process.

- Optimize classroom teaching model, deepen the reform of contents and methods in classroom teaching and practical teaching. On teaching model, invite supervisors and professors with experience in scientific research to integrate achievements in scientific research in classroom teaching, teach creative thoughts and methods, stimulate students' passion in scientific exploration and gradually form the system and operation mechanism to cultivate students' creative spirit and practical ability. In classroom teaching, advocate heuristic teaching, adhere to student-oriented model, follow the principle that lets students find knowledge and carry out thinking innovation on the basis of mastering basic knowledge and basic skills, let students master inner link between knowledge, master knowledge learned by them through comprehensive study, give students the space of active exploration and independent study, pay attention to stimulating the development of students' thinking and intelligence of many aspects, and then make them learn creatively, continuously improve practical ability and make their intellectual activity present diversified and rich requirements, create a kind of lively, vivid as well as up-and-coming teaching atmosphere and guide students to acquire knowledge with creative spirit.

\section{Make Efforts to Create Environment to Cultivate} Innovation Consciousness and Practical Ability.

- It is necessary to cultivate teachers' innovation consciousness. In order to cultivate students' innovation quality, firstly, teachers must have the quality of having the courage to bring forth new ideas. Thoroughly change the "teacher-centered, classroom centered and textbook centered" traditional teaching model and abandon teaching concepts that teach mechanically and stick to dated syllabus and textbook. It is necessary to innovate in teaching model, continuously explore new teaching methods and means and make teaching activities truly become the process to vivify and arouse students' thinking as well as inspire students to innovate. Teachers shall guide students to search for knowledge in traditional knowledge instruction, regard the cultivation of students' innovation consciousness and innovation ability as their own duty. It is the new positioning of innovation education for quality and role of teachers.

- Cultivate creative personality of students. So to speak, if there is no personality, there is no innovation. In order to cultivate students' innovation ability, it is necessary to respect and protect students' personality and exert their strong points. In the process of cultivating students' innovation ability, we must change the concept of traditional educational responsibilities of teachers, namely "pass on knowledge, impart professional knowledge and solve problems", fully pay attention to students' subject consciousness and personality differences, teach students in accordance of their aptitude. It requires teachers to attach importance to cultivating students' curiosity and thirst for knowledge in teaching process, fully develop and create a kind of relaxed environment for students' natural endowment and potential. Only having ebullient mental state can students have the innovation consciousness and inspiration and finally become talents required by the society.

- Create innovation environment in school. As the main place for students' learning, school is not only the organization to spread knowledge but also the paradise to cultivate students' innovation consciousness, innovative thinking, innovative skills and creative personality. Good educational environment is the basis 
and premise for colleges to cultivate creative spirit, and the taste and style for school to embody demands of the time. It requires schools to create a good environment and atmosphere for innovation education, let students become people who have innovation ability truly in this atmosphere. In teaching, it is necessary to renew ideas, create the atmosphere of creation, provide space for creativity, guide students to imagine, stimulate students' creative thinking, thus students can be educated into highly-competent people full of creative spirit and innovation ability.

- Continuously broaden training channels and carriers, actively create environment and atmosphere for innovation education, cultivate and strengthen innovation consciousness of students. Firstly, in terms of characteristics with considerable consciousness of young students in the process of growth, when considering training objectives, educators shall not simply regard educatee as "educational object", but regard educatee as principal participants of development. At present, the educational work must change from simple education and management to guidance, counsel and service and develop from vertical and straight management system to complex network management system. Secondly, it is necessary to strengthen the connotation construction of campus culture, carefully design, strive to build a kind of campus cultural environ ment and academic atmosphere suitable for students to become useful pers ons and fully arouse students' sense of participation and enthusiasm and initiative. In terms of students' mentality of seeking the new and difference, develop strong points of each student and improve students' sense of identity and sense of belonging through multilevel instruction and carrying out various community activities. It helps the sound development of students' personality under edification of integrated environment, make students increase their knowledge and enhance their abilities in activities.

- Create innovation environment that helps students to participate in social practice activities. Students' enthusiasm to participate in innovation activity mainly comes from the aspect that students have strong consciousness of innovation. Therefore, when schools reform course system and contents as well as improve teaching methods, they should pay high attention to students' extra-curricular activities, organically integrate with cultural activity of the campus and social practice activities, and arouse students' enthusiasm to participate in scientific and technological activities, let students benefit from activities, improve and strengthen innovation cons ciousness in activities.

\section{Strengthen Mechanism Construction to Cultivate Innovation Consciousness and Practical Ability}

- Establish sound rules and system of innovation and practice. The reasonable innovation mechanism is the system guarantee to cultivate students' innovation ability. Except for the efforts of society, family and school to cultivate students' innovative and practical ability, it is necessary to further base on reality of schools and students, strengthen construction mechanism of system to cultivate innovation consciousness and practical ability. It helps to achieve organic unification of innovation of the teaching and learning, organic unification of subject innovation and activity innovation, organic unification of innovation inside and outside campus, as well as organic unification of cultivation of innovation consciousness and improve ment of practical ability.

- Establish effective mechanism and encourage the development of innovation ability in teaching. It is necessary for schools to establish effective reward mechanism and gradually form good atmosphere and ethos to encourage, participate in and carry forward innovation. On one hand, give material encouragement for teaching staff and backbone and let their innovative achievements get acknowledgement and corresponding reward of society. On the other hand, stimu late students to carry out innovation activity through a variety of measures such as scholarship, innovation funds, award credit, innovation credit and credit of quality development, provide fund guarantee for students' innovation activities and supervisors' professional counseling, in order to integrate innovation in education, which have immeasurable function and meaning to promote students' quality-oriented education.

- Encourage teachers to actively participate in enterprise practice and internship links. University-enterprise cooperation can produce win-win situation and the effective way to strengthen construction of teaching staff and develop innovation education. On one hand, practice teaching in schools needs enterprise to provide real projects and working environment. Meanwhile, it requires enterprise to provide technicians with rich practical experience to guide students' production practice, in order to cultivate excellent skilled talents; on the other hand, enterprises also hope schools can cultivate outstanding students with practical experience and select professional talents suitable for the enterprise in the process of accepting students to practice. Therefore, in the process of cooperating with enterprises, it is necessary to fully arouse teachers' enthusiasm and initiative from the system, stimulate teachers' enthusiasm to participate in universityenterprise cooperation, formulate corresponding training plan, adopt ways such as project development, technology service and enterprise practice to improve integral level of teachers, enhance teachers' sense of competition and innovation ability, designedly organize professional teachers to go deep into enterprise practice by stages and create favorable condition for teachers to truly participate in practical activities such as production, operation and management of enterprise.

- Establish and improve mechanism of teaching operation. Establishing and improving operation mechanism of innovation teaching is the fundamental guarantee to pursue and cultivate talents with higher 
quality, make efforts to improve the quality of education and teaching and implement the target of teaching management. In the process of teaching management, it can better achieve the target of teaching management and serve teaching management only through establishing effective regulatory framework, continuous innovating, security, supervision and restraint mechanism that can fully and effectively exert its efficiency, making it realize people-oriented situation, excavating people's potential, giving play to subjective initiative of people, encouraging reform and innovation and forming mechanism of academic freedom and academic democracy. Therefore, establishing sound mechanism of teaching operation is the basic requirement to create good and relaxed education environment under new situation, as well as fundamental task to cultivate teachers and students with innovation consciousness and high quality talents with practical ability.

\section{CONCLUSION}

To sum up, the cultivation of innovation consciousness and practical ability of students is a difficult project. Innovation and practice is the core of quality-oriented education as well as a kind of spirit and ability. There are diversified effective methods and means to cultivate innovation consciousness and practical ability of students. The author thinks that through continuous exploration and research, there will be a method and mean suitable for schools and teachers to cultivate innovation consciousness and practical ability of students.

\section{REFERENCES}

[1] Yue Xiaodong, Gong Fang. Formation of Innovative Thinking and Cultivation of Creative Talents [J], Educational Research, 1999, 10

[2] Zhang Fei. Research Report of "Research on Improving Innovation Consciousness and Practical Ability of Students in Vocational School", 2009, 10

[3] Zheng Jinzhou. Inspect Innovative Education: Several Problems in Cultivation of Innovation Ability [J], Educational Research, 2003, 3

[4] Lv Wei. Thinking on Cultivating Innovation Ability of College Students [J], Journal of Capital Normal University (Social Science Edition), supplement ary issue in 2002

[5] Wang Yiquan. Research and Practice on Cultivation System of Creative Spirit and Practical Ability of Students, Petroleum Education, 09, 1st issue

[6] Fu Guangwan. Analysis on Policy Environment in the Process of Innovation Ability Cultivation of College Students, Theory Monthly, 2003, (8): 137-138 